\title{
Transmission and Suppression of Avian Influenza Virus
}

\author{
Tai-Jin Kim1, Kyung-Hoon Jung'2, Yeong-Sang Kim³ \\ ${ }^{1}$ Department of Chemical Engineering, University of Suwon, Hwasung, South Korea \\ ${ }^{2}$ Department of Food Nutrition, University of Suwon, Hwasung, South Korea \\ ${ }^{3}$ Animal and Plant Quarantine Agency, Gimcheon, South Korea \\ Email: tjkim@suwon.ac.kr
}

How to cite this paper: Kim, T.-J., Jung, K.-H. and Kim, Y.-S. (2018) Transmission and Suppression of Avian Influenza Virus. Advances in Bioscience and Biotechnology, 9, 661-678.

https://doi.org/10.4236/abb.2018.912045

Received: November 20, 2018

Accepted: December 21, 2018

Published: December 24, 2018

Copyright $\odot 2018$ by authors and Scientific Research Publishing Inc. This work is licensed under the Creative Commons Attribution International License (CC BY 4.0).

http://creativecommons.org/licenses/by/4.0/

(c) (i) Open Access

\begin{abstract}
The growth of AIV is possible with supply of minerals from aeolian desert dust, as cofactors of enzymes, and thus the blockage of the aeolian desert dusts to the poultry farmhouse is important to suppress the enzymatic activity of AIV. South Georgia of Subantarctic Islands may be the source of Continental AIV, so that Continental AIV can become endemic within the local bird population when surrounding environments are close to Subantarctica of South Georgia. There are food webs in sequence of aquatic virus, bacteria, phytoplankton, zooplankton, krill, fish and squid while penguins feed on the fish or squid infected by mutant virus to generate LPAI after an incubation period. When migratory birds move to the Continents, HPAI can spread in the Continents due to low UV-B radiation, enough feed of rice, wheat, corn, wetland, and mineral-enriched desert dust. The clean room is equipped with air washers to remove aeolian dusts and migratory birds feces from working personnel and equipments, heaters to keep the pasteurisation of ultra-high temperature at $135^{\circ} \mathrm{C}$ for $1-2$ seconds to inactivate AIV, humidifier to keep wet state above $65 \%$ relative humidity for weak virus activity, and the UV-C lamps $(254 \mathrm{~nm})$ to finally inactivate AIV. Since AIV doesn't like the high salinity and high relative humidity, seawater is blanketed as sprayer to maintain high salinity (>20 ppt) and high relative humidity ( $>65 \%)$ from the top to the bottom of the poultry farmhouses for suppression of AIV transmission from infected aeolian dust coming from outside.
\end{abstract}

\section{Keywords}

Transmission, Suppression, Avian Influenza Virus, Desert Dust, Poultry Farmhouse 


\section{Introduction}

Avian influenza viruses (AIV) spread by a number of means including movement of live birds, movement of people and equipment, movement of poultry, contaminated poultry food or water, airborne spread, contaminated vaccines, and non-avian host [1]. AIV is transmitted by direct contact between infected and susceptible birds and indirectly through exposure to aerosol or fomites contaminated with the AIV. Influenza viruses replicate in wild ducks and are excreted with the faeces into lake water. The virus may be passed to their susceptible birds through lake or drinking water with viral infectivity for up to 207 days at $17^{\circ} \mathrm{C}$ [2]. There were strong links between the number of AIV outbreaks, the density of free grazing ducks, rice feed production, along with wild bird populations, distribution, migratory routes, and stop-over sites. During the dry season, the irrigated rice paddy fields, form the important wetland habitat for wild waterfowls, thus increasing virus transmission to the local poultry in East Asia [3].

The transition from low pathogenic avian influenza (LPAI) to highly pathogenic avian influenza (HPAI) was dependent upon environmental parameters such as host cell, wild bird, aeolian dust, mudfish, catfish, bullfrog, penguin, wetland, rice farmland, UV-B radiation, temperature, relative humidity, rainfall, poultry population, human population, algae, deep freezer in the Poles $\left(-80^{\circ} \mathrm{C}\right)$ for natural permanent storage of strains, cold freezer $\left(-20^{\circ} \mathrm{C}\right)$ and refrigerator $\left(4^{\circ} \mathrm{C}\right)$ for activation of frozen strains in Antarctic Peninsula, rice and wheat crop productions, prey-predator mechanism, mud soils, and October to December AIV persistence in waters. Removal of aeolian dusts from the inside of poultry farmhouses is important to control AIV transmission and infection. Kim [4] proposed that ultraviolet (UV) radiation is an efficient measure to suppress the outbreak of AIV. Viruses are the most abundant biological particles in the sea and are thought to play an important role in the structure and functioning of aquatic ecosystems. Penguins, as birds, can have a weak immunity to the mutant virus due to a shortage of algae beneath the ice in winter, especially during the period of the minimal sunspot number with strong UV radiation and warm air surface temperature [4]. Such a weak penguin infected by mutant virus can generate and hold LPAI to be transmitted to the Continents via migratory birds. There are good reservoirs for AIV persistence in water (wetland, rice paddy), air (aeolian dust from desert), feed (mudfish, catfish, bullfrog, rice, wheat, corn) to infect poultry farms either in LPAI or HPAI with various mutants of AIV. Inlet air to the inside of poultry farmhouse passed through serial biosecurity such as High Efficiency Particulate Air (HEPA) filters and glass wools for microorganism, $\mathrm{CaO}$ for chemical reaction with water to produce heat $\left(200^{\circ} \mathrm{C}\right)$ and high $\mathrm{pH}$ (>11) during the conversion to $\mathrm{CaCO}_{3}$, and UVC (254 nm) radiation lamp for inactivation of AIV at incoming air streams. Outbreaks of AIV occurred in waters (reservoir, lake, river, wetland, tidal mud flat) and rice production areas from November to January peaking in December in Korea in 2016. Since the outbreak of AIV is the same as the life of mudfish, mudfish near the poultry 
house should be eliminated before October to suppress AIV. The spring water drilled more than $100 \mathrm{~m}$ below was used as the drinking water without sterilization.

The present study investigated the transmission and suppression of AIV with affecting parameters; enzymes, aeolian desert dust, reservoirs, relative humidity, salinity, UV radiation, aquatic microorganisms, temperature, and food webs.

\section{Growth of AIV with Enzyme}

Enzymes possess complex structures with a variety of reactive amino acid side chains to provide catalytic activities. Enzymes accelerate specifically the biosynthesis of macromolecules such as polysaccharides, lipids and proteins for growth of AIV, as shown in Figure 1. It is important to supply minerals [5]-[13] from aeolian desert dusts for the growth of AIV. Therefore, the blockage of the aeolian dust in poultry farmhouse should be the first step to suppress the outbreak of AIV.

\section{Aeolian Desert Dust}

Major aeolian dust events arise from the Sahara and Sahel deserts ("African dust"), the Australian deserts ("Australian dust"), and the Taklamakan and Gobi deserts and the Loess plateau (“Asian dust”) (Table 1). Tanaka and Chiba [14] compared the annual mean global dust fluxes by regions: Africa (61\%; North 58 , South 3), Asia (30.5\%; Arabia 12, Central 7.5, East 11), Australia (6\%), and America (2.1\%; North 0.1, South 2).

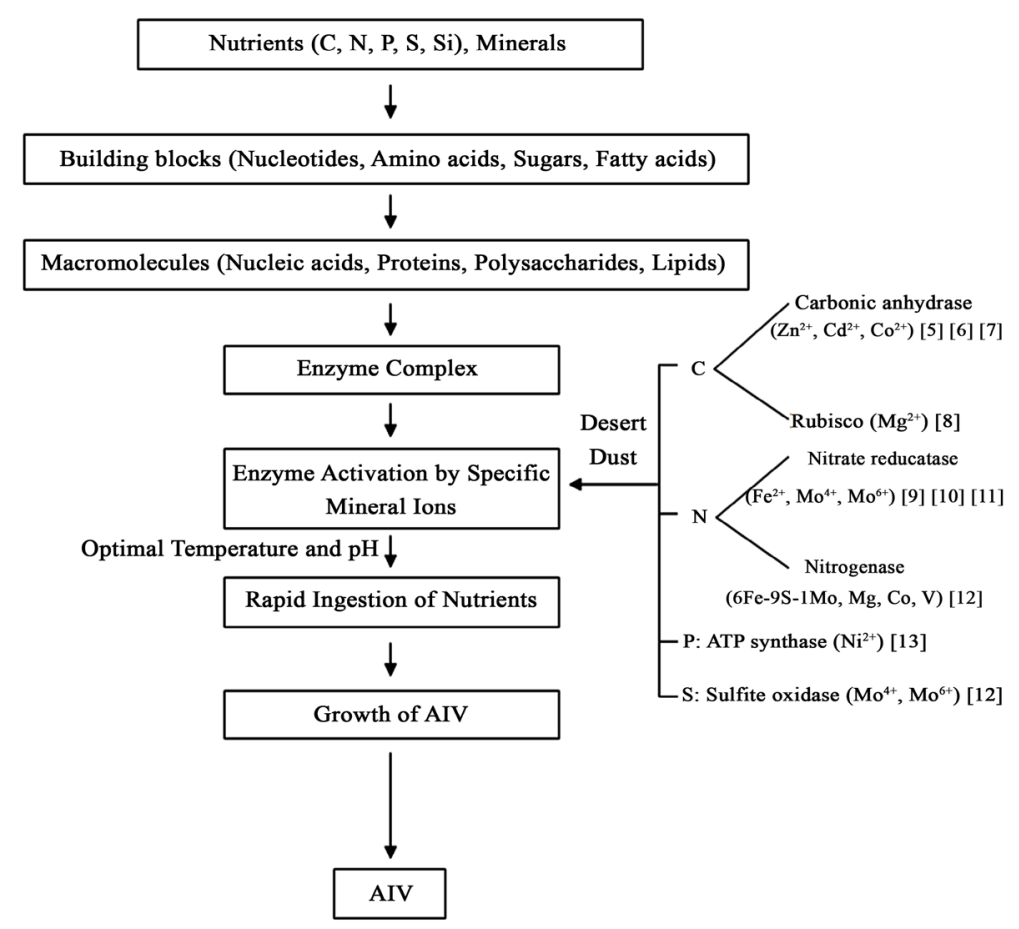

Figure 1. Schematic flow diagram of AIV growth with enzymes activated by mineral ions from aeolian desert dusts. 
Table 1. Global major deserts in the world [19].

\begin{tabular}{ccc}
\hline Continent & $\begin{array}{c}\text { Surface } \\
\text { Area } \\
\left(10^{4} \mathrm{mi}^{2}\right)\end{array}$ & Desert (Country) \\
Antarctica & 550 & Antarctic \\
Arctic & 540 & Arctic (Alaska, Canada, Greenland, Iceland, Norway, \\
Sweden, Finland, Russia)
\end{tabular}

Table 1 suggests that, 1) Antarctica and the Arctic have the largest surface areas of deserts in the world, which can be one of the reasons why such regions are regarded as the sources of AIV, as proposed by Kim [4]. It was revealed that habitat type influenced bacterial community of Actinobacteria and Cyanobacteria in lithobionts and surface soils from Antarctica [15]. Bacteria (Methylobacterium, Brevundimonas, Paenibacillus, Bacillus and Micrococcus) might have been transported and deposited into the coastal Antarctic ice core at sub-zero temperatures along with desert dust particles and marine aerosols [16]. 2) The third largest Saharan aeolian input to the Iberian Peninsula of Spain [17] might have caused the H1N1 1918 Spanish flu, which killed approximately 100 million people around the world. 3) The fourth largest Arabian Desert has been the source of 2012 MERS-CoV. Dromedary camels in the Arabian Desert proved to be positive for MERS-CoV which emerged around July 2007 to June 2012 [18]. 4) The fifth largest Asian aeolian deserts could be the sources of 1996 AIV and 2002-2003 SARS in China. 5) The sixth largest Australian deserts supply iron enriched (17\%) dusts to East Asia and there are extensive AIV outbreaks in the East Asia while no specific diseases have been observed in Australia, presumably due to the ozone layer deterioration inducing strong UV radiation from Antarctica. 6) The seventh largest North American regions have yearly outbreaks of AIV since its location is also on the routes of migratory birds such as Atlantic Americas, Pacific Americas, and Mississippi Americas flyways. It is therefore proposed that global deserts with minerals are sources of the life and disease in the world.

There are ozone hole deteriorations with extensive UV-B radiations in South 
America, South Africa, New Zealand, Australia, Scandinavian countries, Denmark, northern Russia, and northern Canada [4].

Table 2 showing regional distribution of AIV with various strains suggests that Asian and Europe are the main regions of AIV outbreaks. Asia has Chinese deserts along with Australian deserts while Saharan Desert from Africa is blown to Europe. Aeolian dusts from deserts provide the minerals essential for the biosynthesis of protein in AIV growth (Figure 1). Therefore, the prevention of aeolian dust is very important to suppress the AIV outbreak.

\section{Transmission of AIV with Temperature}

South Georgia in Subantarctica showed the highest monthly temperature profile; the average annual temperature of $+1.8^{\circ} \mathrm{C}$, while Orcadas in Antarctic Islands was $-4.3^{\circ} \mathrm{C}$ and Rothera in Antarctic Peninsula was $-5.3^{\circ} \mathrm{C}$ [21]. South Georgia showed the average monthly temperature to be above $0^{\circ} \mathrm{C}$ during October to April, which is exactly overlapped with the period of AIV outbreaks in the Continents. It can be postulated that AIV, originating from South Georgia in the Subantarctic Islands, may be the source of Continental AIV becoming endemic within the local bird population when surrounding environments are close to Subantarctica of South Georgia. Arctic breeding migratory waterfowl are known to be a reservoir and vector for AIV [22]. Wild aquatic birds such as dabbling ducks, gulls, and other shorebirds are considered the natural reservoir for AIV. Wild migratory birds play a key role in the spread of AIV on a local, regional, and intercontinental scale via broadly established flyways, confirmed by sequence and BLAST analysis of gene sequence (hemagglutinin (HA), neuraminidase (NA)). Andélie penguins in Antarctica infected by H11N2 subtype AIV showed ancestry with Eurasian HA, South and North American NA sequences [23]. There were penguins with seropositivity against AIV reflecting previous exposure to AIV; Rockhopper, Macaroni, Gentoo, Chinstrap and King penguins,

Table 2. Regional distribution of AIV with various strains [20].

\begin{tabular}{|c|c|c|c|}
\hline Region & Countries & Strains & $\begin{array}{l}\text { Aggregated count of } \\
\text { poultry destroyed for } \\
\text { ongoing outbreaks }\end{array}$ \\
\hline Asia & $\begin{array}{l}\text { China, Chinese Taipei, India, Korea } \\
\text { (Rep. of), Lao, Nepal, Vietnam }\end{array}$ & $\begin{array}{c}\text { H5N1, H5N2, } \\
\text { H5N6, H5N8, } \\
\text { H7N9 }\end{array}$ & $8,847,706$ \\
\hline Europe & $\begin{array}{c}\text { Bulgaria, France, Germany, Greece, } \\
\text { Croatia, Hungary, Italy, Macedonia } \\
\text { (former Yugoslav Rep. of), Montenegro, } \\
\text { Netherlands, Romania, Russian } \\
\text { Federation, Slovakia, Slovenia, Spain, Sweden }\end{array}$ & $\begin{array}{l}\text { H5, H5N5, } \\
\text { H5N6, H5N8 }\end{array}$ & $2,480,174$ \\
\hline America & United States of America & H7N9 & 127,956 \\
\hline Africa & Cameroon, Egypt, Niger, Nigeria, Uganda & $\mathrm{H} 5 \mathrm{~N} 1, \mathrm{H} 5 \mathrm{~N} 8$ & 10,555 \\
\hline Total & & & $11,466,391$ \\
\hline
\end{tabular}


which indicate the AIV strains have circulated in penguin species in the Subantarctic region [24]. Such sampling sites are located between Chile in South America and the Antarctic Peninsula which have the highest flow rate of Antarctic Circumpolar Current (ACC), Drake Passage of $1.40 \times 108 \mathrm{~m}^{3} / \mathrm{s}$, warm average annual temperature of Antarctic Peninsula $\left(-5.3^{\circ} \mathrm{C}\right)$ and South Georgia $\left(+1.8^{\circ} \mathrm{C}\right)$, abundance of Antarctic krill population, which allow good environment for penguin habitat. It appears that Antarctica is the continuous source and supplier of AIV carried by penguins and transmitted to the Continents through the airways of migratory shorebirds, skuas, petrels, ducks, and waterfowl birds. The distance between Antarctica and Guangdong in China is $1.6 \times$ $10^{4} \mathrm{~km}$ while the velocity of migrating birds was about $15 \mathrm{~m} / \mathrm{s}$ [25]; the non-stop flying time is then 12.2 days. Since the migratory birds move $300 \mathrm{~km}$ every time, there can be at least 5 stop-overs from Antarctica to China. The average monthly temperature falls to below zero degree in May, during which the migratory birds in Subantarctic Islands may start to migrate to China. If every flying run is $300 \mathrm{~km}$ with a speed of $15 \mathrm{~m} / \mathrm{s}$, it may take 28 hours to complete the first flight. Since the flying birds prefer to fly just before or after the sunset to avoid the damage of UV-B radiation, at least 2 or 3 days are required to complete the first $300 \mathrm{~km}$ flight. Since they have to relax and feed to make up the exhausted energy at the stop-over, it may take nearly a month to complete every flight. It can be thus approximated that the migratory birds can arrive in China five months later at around October. Since it takes one (H5N8) to three (H5N1) weeks to express the symptoms of AIV, the outbreaks of AIV are observed in October or November until next April, as shown in H5N8 in 2016, South Korea. It appears that AIV has evolved to adjust to the Subantarctic temperature when carried by penguins, so that the outbreaks of AIV are frequent during October to April. The timing of arrival of migratory birds (skua, shags, petrel, and gulls) that breed in Antarctica overlap with that of penguins as they return to colonies for breeding and nesting during the summer in the Southern Hemisphere. These birds share a habitat, enabling close contact and introducing the possibility of AIV spillover from migratory birds to penguins in the form of low pathogenicity (LP) AIV (H5N5) [26]. Such a persistence of LPAIV in Antarctica could be due to the high UV radiation in Antarctica. That is, strong UV-B radiation may suppress the outbreak of high pathogenicity (HP) AIV in Antarctica with extensive low temperature and low humidity. Penguins (Gentoo, Adélie, Chinstrap) feeding on krill, fish, and squid are living within the Polar Front in cold waters of ACC [27]. There are 17 species of penguin worldwide, 1 species in the Galapagos Islands, 7 species in Antarctic and Subantarctic Islands (Adélie, Chinstrap, Emperor, Gentoo, King, Macaroni and Rockhopper) with the main predators being leopard seals and skuas [28]. Esperanza Base at the tip of the Antarctic Peninsula showed a maximum temperature of $0^{\circ} \mathrm{C}$ from October to March while Vostok station showed a minimum temperature of $-68^{\circ} \mathrm{C}$ to $-72^{\circ} \mathrm{C}$ from April to September [29]. In 1995, Larsen A ice shelf of Antarctic Peninsula collapsed to cause less algal availability during the austral winter period since algae spend the win- 
ter beneath the ice. Krill feed on algae while penguins feed on krill, fish, and squid. Since penguins might have starved due to the collapse of huge icebergs in the Antarctic Peninsula in 1995, it is possible that AIV carried by penguins may have been expressed due to the lack of self immunity and transmitted to the migratory birds for Continental infections (China and Mexico) of AIV in 1995 [4]. Antarctica is similar to a deep freezer $\left(-80^{\circ} \mathrm{C}\right)$ for storage of AIV strains forever until activated and carried by migratory birds via Antarctic and Subantarctic penguins. Strong UV-B radiation in Antarctica with increased temperature may activate and mutate such a stored AIV in the form of a new mutatant AIV to be spread in the Continents via migratory birds in contact with infected penguins. Normally the refrigerator in the house provides $4^{\circ} \mathrm{C}-7^{\circ} \mathrm{C}$, which was analogous to some of the minimum temperature with HPAI H5N1 outbreaks [30]. It has been addressed that the introduction of HPAI (H11N2 in 2013, H11 in 2014, and H5N5 in 2015) into penguin colonies within Antarctica might have devasting consequences [31]. It can be postulated that UV-B radiation in the Antarctica induces AIV in the form of LPAI while its mutant of HPAI is expressed in the Continents when environmental parameters such as low temperature, low relative humidity, low salinity, and low UV radiation are satisfied. It is thus suggested that AIV is not avoidable but an acceptable disease although appropriate controls and treatments on poultry farms may minimize the deaths of chickens, ducks and turkeys [30]. On the other hand there are long-distance migratory birds in Antarctica such as albatrosses, shearwaters, petrels, ducks, geese, swans, sheathbills, skuas, jaegers, gulls, terns, and skimmers [32]. For example, Arctic tern migrated 44,000 miles from Pole to Pole each year, flying between its breeding grounds in Greenland in the North and the Weddell Sea on the shores of Antarctica [33]. There are food webs in the sequence of aquatic virus, bacteria, phytoplankton, zooplankton, krill, fish, and squid while penguins feed on the fish or squid infected by the virus to generate the low pathogenic avian influenza virus (LPAIV) after an incubation period. Such a mutatant AIV is transmitted by migratory birds from Antarctica to the Northern Hemisphere of North America, Europe, Africa, and Asia. There are good reservoirs for AIV persistence in water (wetland, rice paddy), air (aeolian dust from desert), feed (mudfish, catfish, bullfrog, rice, wheat, corn) to infect poultry farms either in LPAI or HPAI with various mutants of AIV. The Ozone hole reaches its annual maximum in September or October, at the end of winter in the Southern Hemisphere [34]. It is likely that migratory birds are AIV infected either in LPAI form or mutant by UV-B radiation. When such birds move to the Northern Hemisphere, HPAI can spread due to weak UV-B radiation and enough feed of rice, wheat, corn, wetland, mineral-enriched desert dust with good environments (low temperature, low relative humidity, low salinity), similar to those of Antarctic Peninsula or Subantarctica with penguins. Figure 2 shows the schematic diagram of the transmission route of AIV from Poles to Continents. AIV in the form of LPAI is generated and mutated by strong UV-B radiation in the Poles to be transmitted to Continents for poultry and humans as LPAI/HPAI. 


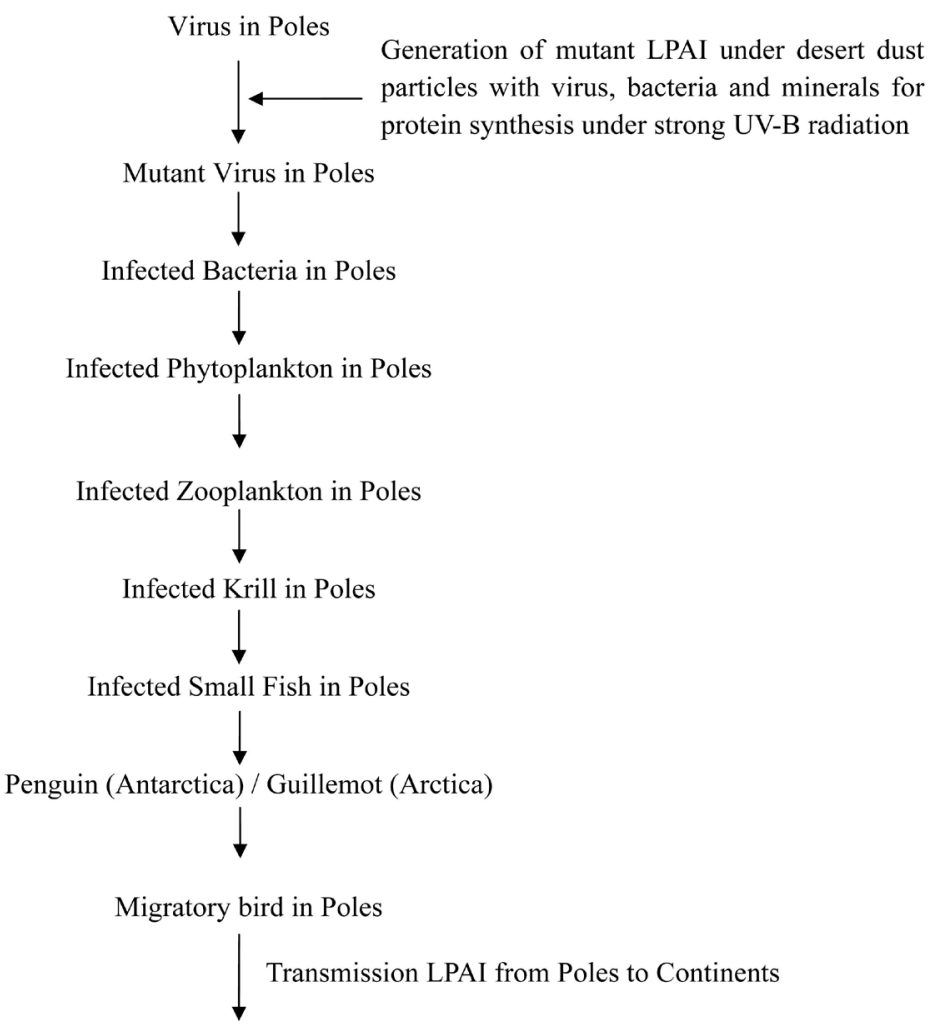

Reservoirs of rice paddy, Wetland, Lake, Tidal mud flat, Coastline,

Wheat, Corn, Bullfrog, Mudfish, Catfish

LPAI/HPAI co-persistence under environments (temperature, relative humidity, salinity, $\mathrm{pH}$, nutrient, UV-B)

Infection of Poultry (chicken, duck, turkey, quail, goose, pheasant, guinea fowl,

pigeon, ostrich), Wild bird and Marine mammal

$\downarrow$ HPAI
Culling Poultry and Dead Humans

Figure 2. Sequential flow diagram of AIV transmission from mutant virus in the Poles as LPAI to poultry and humans in Continents as LPAI/HPAI.

\section{Suppression of AIV}

Figure 2 shows the flow diagram of AIV infected by aquatic virus in the Poles while extensive UV-B radiation during the minimal sunspot number might mutate aquatic food webs to infect penguin and tern at the Poles. Such a mutant AIV is transmitted to migratory birds in the Poles for delivery of new AIV mutants to the Continents in reservoirs of rice paddy, wetland, lake, mud flat with rice, wheat, corn, bullfrog, mudfish, catfish, and lungfish. Infection of poultry and wild bird with AIV caused the culling of poultry and human death by HPAI H5N1 in China. As seen in Figure 2, the possible control steps can be migratory birds, reservoirs, enviroments, and poultry farmhouses, which are almost impossible to mitigate due to wide ranges of covering areas and hosts. However, AIV can be easily suppressed if the target area is limited to the poultry farmhouse and working personnel, equipped with artificial UV-B radiation facilities 
without harming poultry inside farmhouses, which can be maintained by the air purifier to remove the aeolian dust carrying AIV and the UV-B lamp (254 nm) for sterilization of AIV in inlet air and drinking water [4]. Entrance gates of farmhouses may be installed with the clean room similar to the factories of semiconductor chips to avoid the AIV penetration into the poultry farmhouses. Inlet air is passed through serial biosecurity such as High Efficiency Particulate Air (HEPA) filters and glass wools for microorganism and aeolian dusts for prevention of respiratory routes of poultry infection. $\mathrm{CaO}$ for chemical reaction with water produces heat $\left(200^{\circ} \mathrm{C}\right)$ and high $\mathrm{pH}(>11)$ during the conversion to $\mathrm{CaCO}_{3}$. The clean room of the poultry farmhouse is equipped with 1) air washer to remove aeolian dusts and migratory birds feces from working personnel and equipments, 2) heater to keep the pasteurisation of ultra-high temperature at $135^{\circ} \mathrm{C}$ for $1-2$ seconds to inactivate $\mathrm{AIV}, 3$ ) humidifier to keep a wet state above $60 \%$ relative humidity for weak virus activity, and 4) UV-C lamp (254 nm) for inactivation of AIV. It is known that UV highly varies at the Earth's surface to damage biological organisms [35]. UV lamp has merits such as, 1) easy to use within a short time of sterilization, 2) sterilize any microorganisms without resistance, 3) no smell or taste, and 4) no harmful byproducts. Drinking water is widely sterilized by methods of ozone, chlorination, and ultraviolet (UV). Sterilization method by UV is conducted by UV lamps installed inside of quartz tubes to inactivate the microorgansms in the path of drinking water [4].

Figure 3 showed the hourly distribution of UV-B intensity during one day in Korea (2013.07.25), reaching its maximal peak at noon. High elevation between 4300 and $5916 \mathrm{~m}$ above sea level in the thin Bolivian ozone layer and clear sky produced intensive ultraviolet (UV) radiation in the tropical Andes [36]. When working personnel enters the farmhouse, he should wear 1) goggles laminated with green color as a barrier against UV [37] before entering the clean room to protect his eye disorders such as cataracts or retinal damage [4], 2) mask to prevent the inhalation of infected aeolian dusts, 3) wear the disposable white gown from head to feet for prevention of AIV contamination, 4) and change his shoes without any soils contaminated by migratory birds feces.

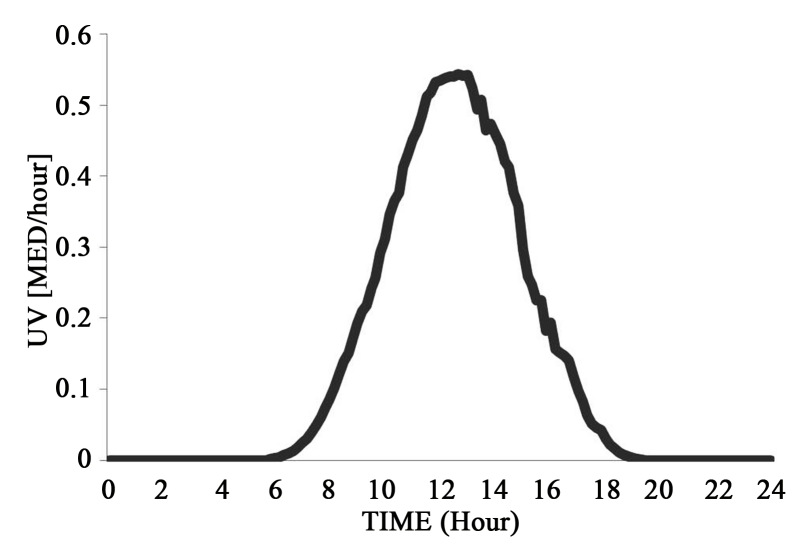

Figure 3. Hourly distribution of UV intensity during one day (2013.07.25) in Korea (data from [38]). 
During minimal sunspot area [4] there are increases of ozone hole deterioration to cause extensive UV-B radiation, which induce the mutant virus to infect prey (virus, bacteria, phytoplankton, zooplankton, krill, small fish, squid) and predators (penguins, migratory birds) with LPAI in Poles and HPAI in Continents with exchange of AIV remaining infective for 30 - 207 days in water [2] among rice, domestic poultry and migratory waterbirds. Figure 4 describes the transmission of AIV from reservoir to predator under environmental climates.

Table 3 shows the stepwise transmission process of AIV from the mutant virus in the Poles to infect poultry in the Continents. AIV primarily affects birds, but certain strains of these bird viruses can become infectious to other species including pigs, cats, humans [39] and mammals [40].

The period of January to March is generally considered the peak of the H5N1 HPAI season, when outbreak numbers increase following an active period of disease events/reports (October to December) [41]. HPAI H5N6 is very fast

Physical Phase of Reservoir

Solid Phase; Aeolian Dust

Biological Phase; Virus, Bacteria, Algae, Krill, Fish, Penguin, Guillemot

Water Phase; Wetland, Swamp, River, Lake, Estuarine, Reservoir

Prey; Rice, Wheat, Mudfish, Catfish, Lungfish, Small Fish

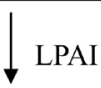

\begin{tabular}{|c|c|}
\hline Predator & Migratory Birds infected by LPAI in Poles \\
& $\downarrow$ LPAI/HPAI
\end{tabular}

AIV infected poultry by either LPAI or HPAI depending upon transmission strain and environmental climates (temperature, humidity, aerosol, $\mathrm{pH}$, salinity, UV-B radiation, water) in Continents

Figure 4. Transmission of AIV from physical phase of reservoir to predator under environmental climates.

Table 3. Stepwise transmission process of AIV.

\begin{tabular}{ccc}
\hline Step & Process & Component \\
\hline 1 & Mutation & Virus, AIV, LPAI \\
2 & Aquatic Prey & $\begin{array}{c}\text { Virus, Bacteria, Phytoplankton, Zooplankton, } \\
\text { Krill, Shrimp, Fish, Mudfish, Bullfrog, Crab }\end{array}$ \\
& Transmission & Penguin, Waterfowl, Migratory bird, \\
& Reservoir & Humpback whale \\
4 & Poultry & River, Lake, Pond, Tidal mud flat, Soil, \\
& & Desert dust, Wetland, Rice paddy \\
& & Chicken, Duck, Turkey, Quail
\end{tabular}


spreading and pathogenic in stop-over water of migratory birds and concentrated farmhouses. The outbreaks of AIV H5N1 preferred the low temperature between $-10^{\circ} \mathrm{C}$ and $+20^{\circ} \mathrm{C}$ [42]. Relative humidity $\left(H_{R}\right)$ is defined as the ratio of the partial pressure of water $\left(P_{W}\right)$ to the vapor pressure of the water $\left(P_{W}^{*}\right)$ at the water vapor temperature $(T)$ as,

$$
H_{R}=100 \frac{P_{W}}{P_{W}^{*}}
$$

Since $\left(P_{W}^{*}\right)$ is given by temperature, the relative humidity $\left(H_{R}\right)$ can be determined by knowing water vapor pressure per dry air $\left(P_{W}\right)$ at given temperature $(T)$ from humidity chart [43] or humidity meter. The average annual mean relative humidity (\%) for the McMuro Dry Valleys in East Antarctica showed from $55 \%$ to $74 \%$ while the air temperature was from $-27.4^{\circ} \mathrm{C}$ to $-17.7^{\circ} \mathrm{C}$ [44]. Maintaining indoor relative humidity $>40 \%$ significantly reduced the infectivity of the aerosolized virus [45].

Since AIV doesn't like the high salinity $(>2 \%)$ and high relative humidity $(>65 \%)$, seawater is blanketed as sprayer from the top to the bottom of the poultry farmhouse to prevent AIV transmission from outside infected aerosol, as shown in Figure 5.

Persistence of AIV was present with mudfish and muds while the incubation period of AIV was 7 to 21 days. The outbreak of AIV is from September to April while the life of mudfish is the same and the mud is contaminated by AIV. It is necessary to eliminate mudfish near the poultry house before September for suppression of AIV. $0^{\circ} \mathrm{C}<$ Temperature $<20^{\circ} \mathrm{C}, 60 \%<$ Humidity $<80 \%$, atmospheric pressure was near $1000 \mathrm{KPa}, 1<$ Wind speed $<3 \mathrm{~m} / \mathrm{s}$ for climate factors with H5N1 and H7N9 influenza infection in China [46]. Therefore, persistence of AIV was prevented by water at temperature $\left(>28^{\circ} \mathrm{C}\right)$, salinity $(>20 \mathrm{ppt})$, and $\mathrm{pH}(>8.2)$ [47].

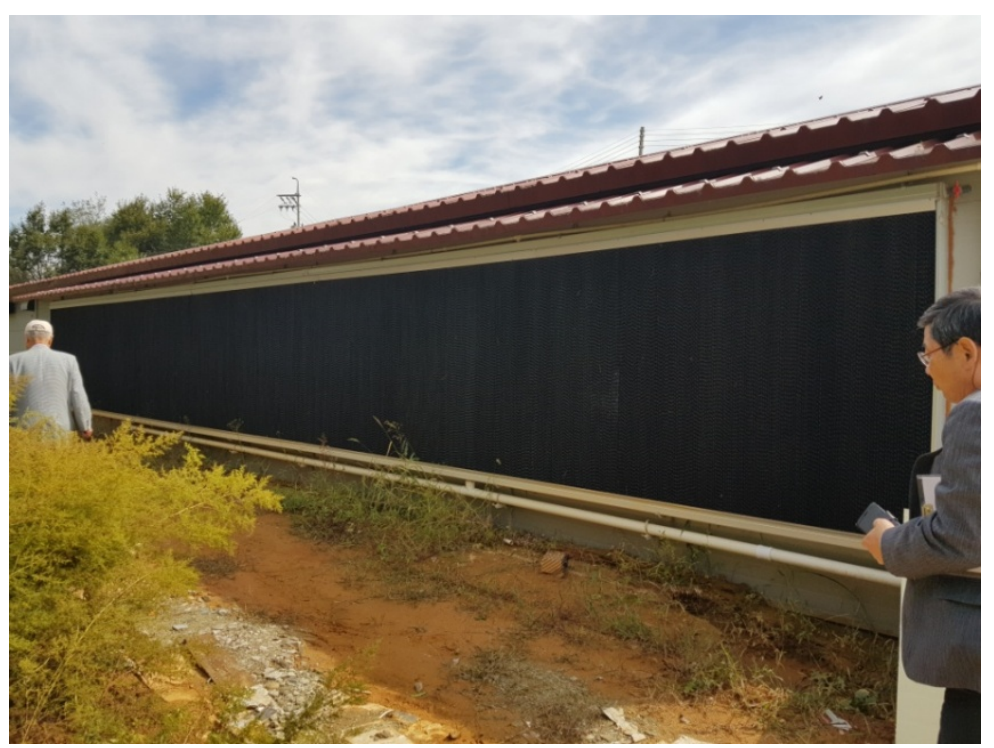

Figure 5. Seawater curtain to suppress AIV in aeolian dusts. 
AIV was persistent in water during rice growth, whose AIV infected water can be the drinking water for migratory birds and poultry. The sterilization of such contaminated waters can be done by physical methods (UV radiation, boiling and cooling) and chemical methods (ozone treatment, $\mathrm{CaO}$ treatment for high $\mathrm{pH}\left(11\right.$ - 12) and high temperature $\left(200^{\circ} \mathrm{C}\right)$ during the chemical reaction with water). The spring water drilled more than $100 \mathrm{~m}$ below was easily used as the drinking water without sterilization. The highest country of melanina skin cancer showed the least outbreak of AIV [4]. In response to high solar UV at the Antarctic Peninsula, algae (picoplankton, phytoplankton, zooplankton, copepod) decreased inducing the mutant viruses in decreased numbers of krill and finally penguins with the consequent outbreak of LPAI AIV [48]. Extensive UV radiation may cause the abnormal cell mutation in the skin and other organs for cancers. In Antarctica, penguins have been exposed to the extensive UV radiation for 45,000 years as reservoirs of LPAI. Such a LPAI has been transmitted to migratory birds breeding in the Poles to be carrried to the Continents with low UV radiation, where LPAI is transformed to HPAI under preferred environmental factors such as low UV radiation, rice or wheat productions, low temperature and salinity, appropriate $\mathrm{pH}$, aeolian dust, concentrated poultry farmhouses, wetlands, rivers, lakes, reservoirs, catfish, lungfish, mudfish, mud, and tidal mud flats (Figure 2).

Table 4 shows the regional transmission of AIV with environmental factors (UV-B, temperature, salinity, relative humidity, desert dust) along with reservoir and feed. It is expected that there are regioal variations of AIV strains although the period of outbreak is similar from October to April.

\section{Migratory Birds Flyways}

Two major mechanisms may be responsible for the geographic spread of avian influenza: wild bird migration and trade. Migratory birds typically migrate twice a year, following warmer weather north during the Northern Hemisphere summer, and south during the Northern Hemisphere winter as shown in Figure 6.

There outbreaks of HPAI and LPAI locations in South Korea were shown in Figure 7 while its weekly time profile from 2016-2017 in Figure 8.

The first outbreak in Korea was shown in wild birds at Cheonan as HPAI H5N6 on November 10, 2016. Poultries of 327,770,000 were culled and buried until January 27, 2017. Outbreaks of AIV occurred in waters (reservoir, lake, river, wetland, tidal mud flat) and rice production areas (Figure 7) from November to January (Figure 8) with its peak in December in South Korea.

\section{Conclusion}

The growth of AIV is possible with supply of minerals from aeolian desert dust, as cofactors of enzymes, and thus the blockage of the aeolian desert dusts to the poultry farmhouse is important to suppress the enzymatic activity of AIV. The average monthly temperature of South Georgia in the Subantarctic Islands is 


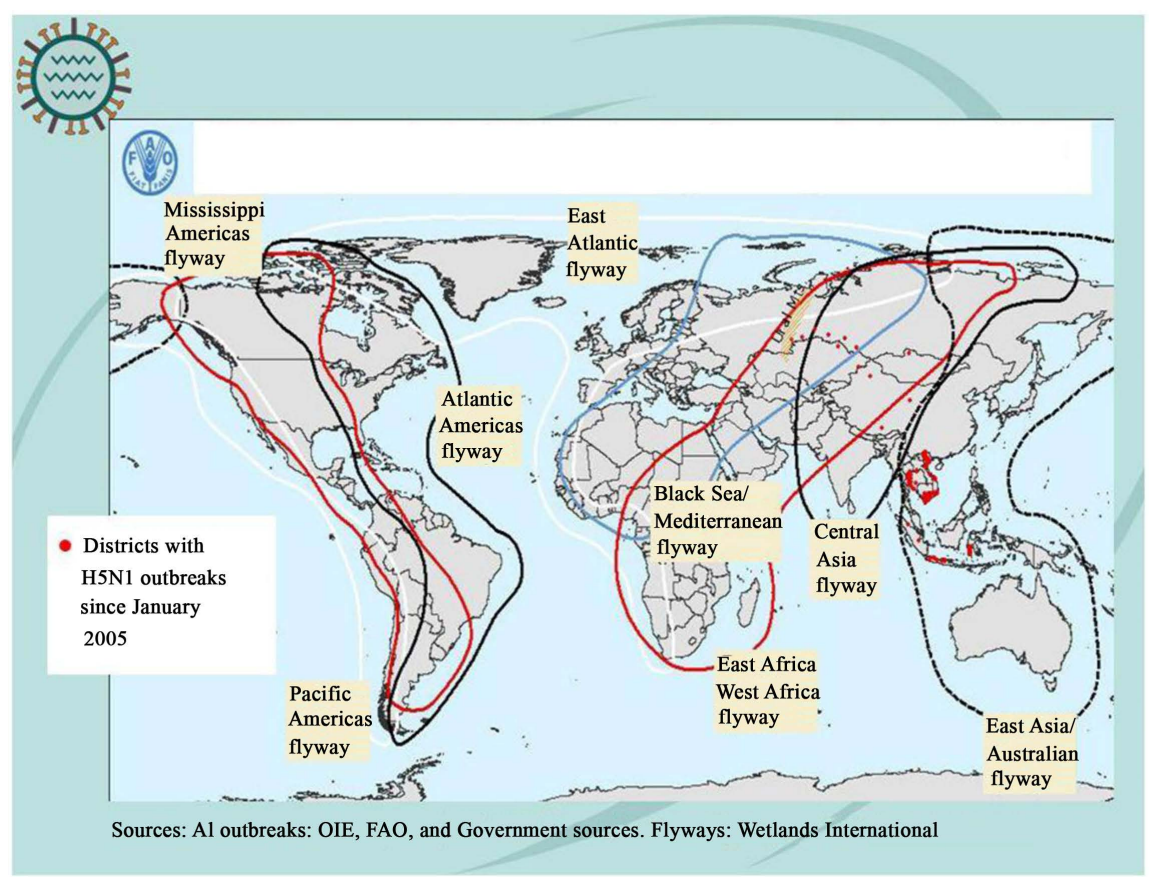

Figure 6. H5N1 outbreaks since 2005 and major flyways of migratory birds [49].

Table 4. Regional transmission of AIV with environmental factors.

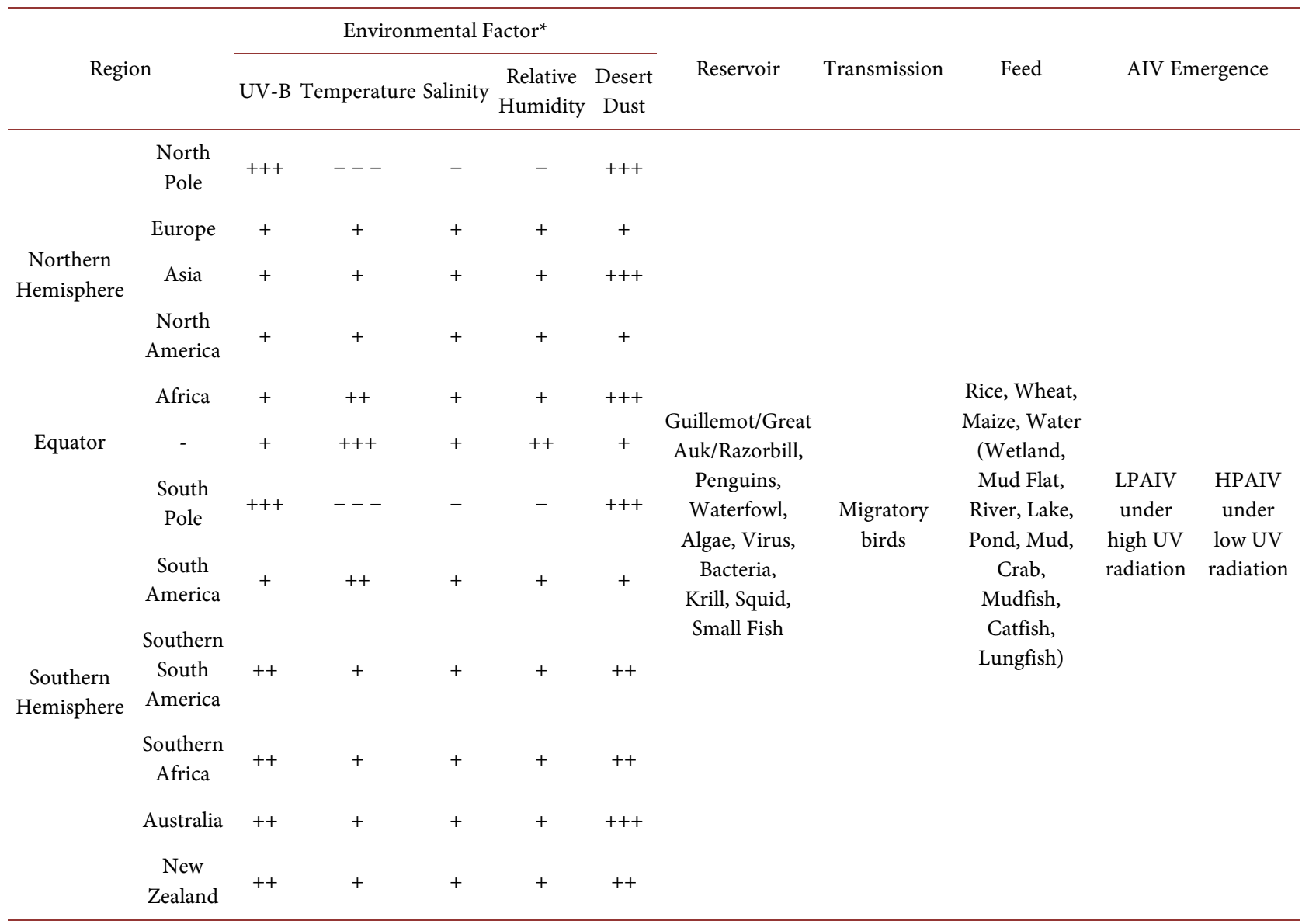

${ }^{\star}$ Note: +++: extensively high, ++: high, +: mild, -: low, - - -: extensively low. 

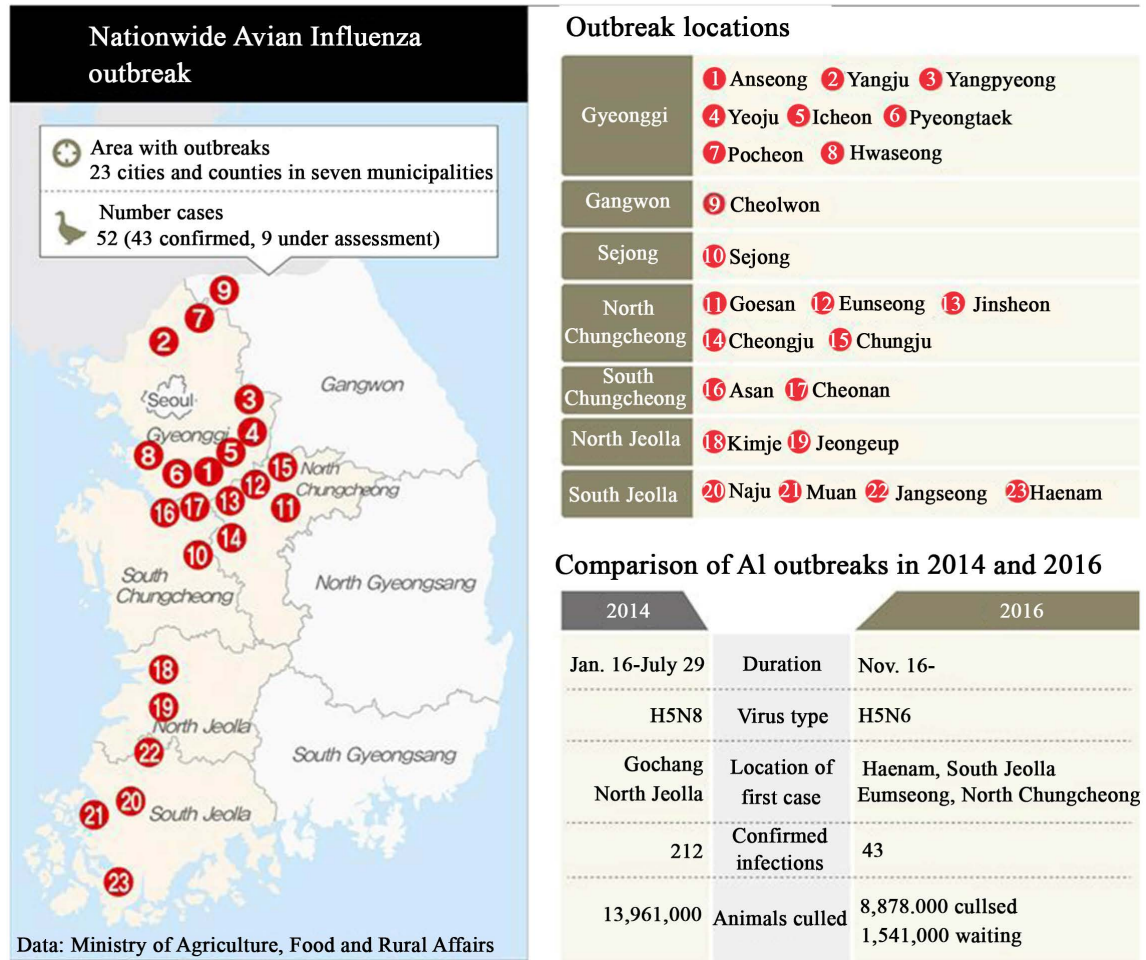

Figure 7. Outbreaks of AIV locations in South Korea [50].

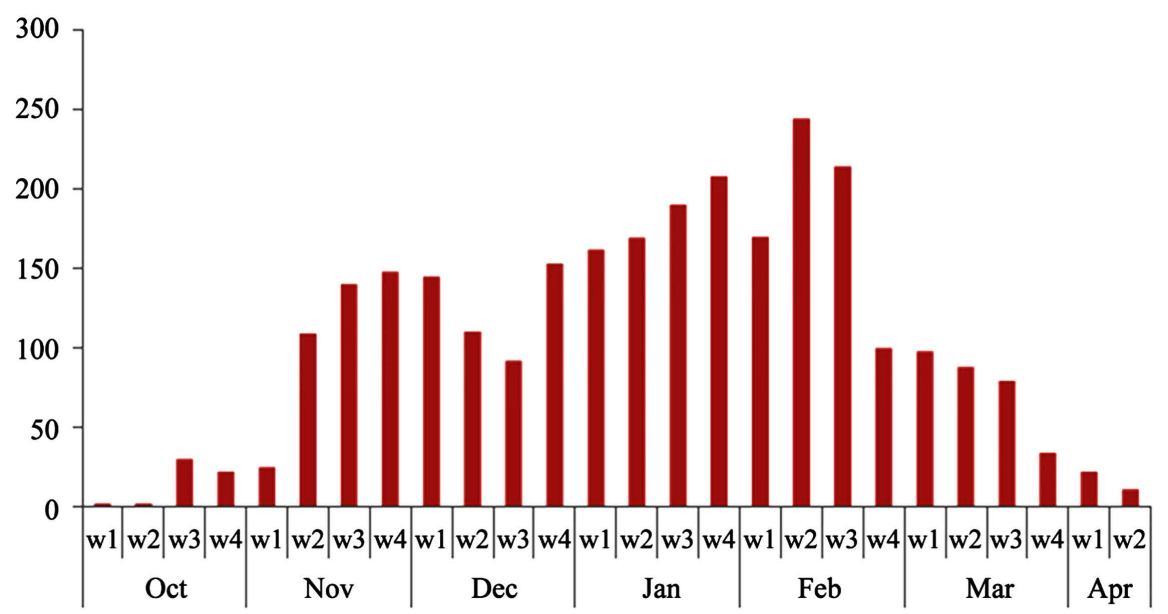

Figure 8. Weekly profile of AIV outbreak frequencies during 2016 to 2017 [20].

above $0^{\circ} \mathrm{C}$ from October to April, which exactly overlapped with periods of AIV outbreaks in the Continents. South Georgia of Subantarctic Islands may be the source of Continental AIV, so that Continental AIV can become endemic within the local bird population when surrounding environments are close to Subantarctica of South Georgia. There are food webs in sequence of aquatic virus, bacteria, phytoplankton, zooplankton, krill, fish and squid while penguins feed on the fish or squid infected by mutant virus to generate LPAI after an incubation period. Such a mutatant AIV is transmited by migratory birds from the Poles to the Continents of North America, Europe, Africa, and Asia. When migratory 
birds move to the Continents, HPAI can spread in the Continents due to low UV-B radiation, enough feed of rice, wheat, corn, wetland, and desert dust with good environments (low temperature, low relative humidity, low salinity), similar to those of the Antarctic Peninsula or Subantarctica with penguins. Entrance gates of poultry farmhouses can be installed with a clean room similar to the factories producting semiconductor chips to avoid the AIV penetration into poultry farmhouses. The clean room is equipped with air washers to remove aeolian dusts and migratory birds feces from working personnel and equipments, heaters to keep the pasteurisation of ultra-high temperature at $135^{\circ} \mathrm{C}$ for 1 - 2 seconds to inactivate AIV, humidifier to keep wet state above $65 \%$ relative humidity for weak virus activity, and the UV-C lamps $(254 \mathrm{~nm})$ to finally inactivate AIV. In Antarctica, penguins have been exposed to the extensive UV radiation for 45,000 years as reservoirs of LPAI. Such a LPAI has been transmitted to migratory birds breeding in the Poles to be carried to the Continents with low UV radiation, where LPAI is transformed to HPAI under preferred environmental factors such as low UV radiation, rice production, low temperature and salinity, appropriate $\mathrm{pH}$, aeolian dust, concentrated poultry farmhouses, wetlands, rivers, lakes, reservoirs, catfishes, lungfishes, mudfishes, muds, and tidal mud flats. Since AIV doesn't like the high salinity and high relative humidity, seawater is blanketed as sprayer to maintain high salinity ( $>20 \mathrm{ppt}$ ) and high relative humidity ( $>65 \%$ ) from the top to the bottom of the poultry farmhouses for suppression of AIV transmission from infected aeolian dust coming from outside.

\section{Acknowledgements}

The author expresses sincere gratitude to G-LAND and the University of Suwon of South Korea for their financial supports. Editing work undertaken by Professor Jonathan Wright is also greatly appreciated.

\section{Conflicts of Interest}

The authors declare no conflicts of interest regarding the publication of this paper.

\section{References}

[1] Stanislawek, W.L., Wilks, C.R., Meers, J., Horner, G.W., Alexander, D.J., Manvell R. J., Kattenbelt, J.A. and Gould, A.R. (2002) Avian Paramyxoviruses and Influenza Viruses Isolated from Mallard Ducks (Anas platyrhynchos) in New Zealand. Archives of Virology, 147, 1287-1302. https://doi.org/10.1007/s00705-002-0818-2

[2] Muzaffar, S.B., Takekawa, J.Y., Prosser, D.J., Newman, S.H. and Xiao, X. (2010) Rice Production Systems and Avian Influenza: Interactions between Mixed-Farming Systems, Poultry and Wild Birds. Waterbirds, 33, 219-230. https://doi.org/10.1675/063.033.s116

[3] Gilbert, M., Xiao, X., Chaitaweesub, P., Kalpravidh, W., Premashthira, S., Boles, S. and Slingenbergh, J. (2007) Avian Influenza, Domestic Ducks and Rice Agriculture 
in Thailand. Agriculture, Ecosystems \& Environment, 119, 409-415. https://doi.org/10.1016/j.agee.2006.09.001

[4] Kim, T.J. (2018) Prevention of Avian Influenza Virus by Ultraviolet Radiation and Prediction of Outbreak by Satellite Parameters. Journal of Biomedical Science and Engineering, 11, 182-206. https://doi.org/10.4236/jbise.2018.117015

[5] (2005) Annual Review of Plant Biology. 56. https://www.annualreviews.org/

[6] Wikipedia (2014) Carbonic Anhydrase. Wikimedia Foundation, Inc.

[7] Bhagat, C., Shantilal, T., Ghelani, A., Dudhagara, P. and Patel, R. (2014) Bio Remediation of $\mathrm{CO}_{2}$ and Characterization of Carbonic Anhydrase from Mangrove Bacteria. Journal of Environmental Science and Technology, 7, 76-83. https://doi.org/10.3923/jest.2014.76.83

[8] Wikipedia (2014) RuBisCO. Wikimedia Foundation Inc.

[9] Lobban, C.S. and Harrison, P.J. (1994) Seaweed Ecology and Physiology. Cambridge University Press, Cambridge. https://doi.org/10.1017/CBO9780511626210

[10] Gao, Y., Smith, G.J. and Alberte, R.S. (2000) Temperature Dependence of Nitrate Reductase Activity in Marine Phytoplankton: Biochemical Analysis and Ecological Implications. Journal of Phycology, 36, 304-313. https://doi.org/10.1046/j.1529-8817.2000.99195.x

[11] Kristiansen, S. (1983) The Temperature Optimum of the Nitrate Reductase Assay for Marine Phytoplankton. Limnology and Oceanography, 28, 776-780. https://doi.org/10.4319/lo.1983.28.4.0776

[12] Dominic, B., Zani, S., Chen, Y.B., Mellon, M.T. and Zehr, J.P. (2000) Organization of the nif Genes of the Nonheterocystous Cyanobacterium Trichodesmium sp. IMS101. Journal of Phycology, 36, 693-701. https://doi.org/10.1046/j.1529-8817.2000.99208.x

[13] Tymoczko, J.L., Berg, J.M. and Stryer, L. (2010) Stryler Biochemistry: A Short Course. 2nd Edition, Freeman and Company, New York.

[14] Tanaka, T.Y. and Chiba, M. (2006) A Numerical Study of the Contributions of Dust Source Regions to the Global Dust Budget. Global and Planetary Change, 52, 88-104. https://doi.org/10.1016/j.gloplacha.2006.02.002

[15] Van Geothem, M.W., Makhalanyane, T.P., Valverde, A., Cary, S.C. and Cowan, D.A. (2016) Characterization of Bacterial Communities in Lithobionts and Soil Niches from Victoria Valley, Antarctica. FEMS Microbiology Ecology, 92, fiw051. https://doi.org/10.1093/femsec/fiw051

[16] Antony, R., Krishnan, K.P., Laluraj, C.M., Thamban, M., Dhakephalkar, P.K., Engineer, A.S. and Shivaji, S. (2012) Diversity and Physiology of Culturable Bacteria Associated with a Coastal Antarctic Ice Core. Microbiological Research, 167, 372-380. https://doi.org/10.1016/j.micres.2012.03.003

[17] Jiménez-Espejo, F.J., García-Alix, A., Jiménez-Moreno, G., Rodrigo-Gámiz, M., Anderson, R.S., Rodríguez-Tovar, F.J., Martínez-Ruiz, F., Giralt, S., Delgado Huertas, A. and Pardo-Igúzquiza, E. (2014) Saharan Aeolian Input and Effective Humidity Variations over Western Europe during the Holocene from a High Altitude Record. Chemical Geology, 374-375, 1-12. https://doi.org/10.1016/j.chemgeo.2014.03.001

[18] Ahmad, Z., Singh, K., Akhtar, J., Amir, M., Parveen, Z. and Shakya, P. (2017) Middle East Respiratory Syndrome-Coronavirus (MERS-CoV) in India and Abroad. International Journal of Pharmaceutical Sciences and Research, 8, 4496-4512.

[19] The World's Largest Deserts. https://geology.com 
[20] World Organisation for Animal Health (2017).

[21] Kejna, M. (2003) Trends of Air Temperature of the Antarctic during the Period 1958-2000. Polish Polar Research, 24, 99-126.

[22] Klaassen, M. (2006) Migratory Birds as Vectors for Influenza Dispersal. International Journal of Infection Control, 2, 1.

[23] Hurt, A.C., Vijaykrishna, D., Butler, J., Baas, C., Maurer-Stroh, S., Silva-de-la-Fuente, M.C., Medina-Vogel, G., Olsen, B., Kelso, A., Barr, L.G. and González-Acuna, D. (2014) Detection of Evolutionarily Distinct Avian Influenza A Viruses in Antarctiva. mBio, 5, e01098. https://doi.org/10.1128/mBio.01098-14

[24] Abad, F.X., Busquets, N., Sanchez, A., Ryan, P.G., Majo, N. and Gonzalez-Soli's, J. (2013) Serological and Virological Surveys of the Influenza A Viruses in Antarctic and Sub-Antarctic Penguins. Antarctic Science, 25, 339-344.

[25] Farnsworth, A., Sheldon, D., Geevarghese, J., Irvine, J., Doren, B.V., Webb, K., Dietterich, T.G. and Kelling, S. (2014) Reconstructing Velocities of Migrating Birds from Weather Radar-A Case Study in Computational Sustainability. AI Magazine, 35, 2. https://doi.org/10.1609/aimag.v35i2.2527

[26] Barriga, G.P., Boric-Bargetto, D., Martin, M.C.S., Neira, V., Bakel, H.V., Thompsom, M., Tapia, R., Toro-Ascuy, D., Moreno, L., Vasquez, Y., Sallaberry, M., Torres-Pérez, F., González-Acuña, D. and Medina, R.A. (2016) Avian Influenza Virus H5 Strain with North American and Eurasian Lineage Genes in an Antarctic Penguin. Emerging Infectious Diseases, 22, 2221-2223.

[27] Clucas, G.V., Dunn, M.J., Dyke, G., Emslie, S.D., Levy, H., Naveen, R., Polito, M.J., Pybus, O.G., Rogers, A.D. and Hart, T. (2014) A Reversal of Fortunes: Climate Change "Winners" and "Losers" in Antarctic Peninsula Penguins. Scientific Reports, 4, 5024.

[28] http://www.penguins.cl/penguins-species.htm

[29] http://www.climatestotravel.com/climate/antarctica

[30] Liu, C.M., Lin, S.H., Chen, Y.C., Lin, K.C.M., Wu, T.S.J. and King, C.C. (2007) Temperature Drops and the Onset of Severe Avian Influenza A H5N1 Virus Outbreaks. PLoS ONE, 2, e191. https://doi.org/10.1371/journal.pone.0000191

[31] Hurt, A.C., Su, Y.C., Abam, M., Peck, H., Lau, H., Baas, C., Deng, Y.M., Spirason, N., Ellström, P., Hernandez, J., Olsen, B., Barr, I.G., Vijaykrishna, D. and Gonzalez-Acuna, D. (2016) Evidence for the Introduction, Reassortment, and Persistence of Diverse Influenza A Viruses in Antarctica. Journal of Virology, 90, 9674-9682.

[32] http://en.m.wikipedia.org/wiki/List_of_birds_of_Antarctica

[33] https://www.independent.co.uk/environment/nature/pole-to-pole-the-extraordinar y-migration-of-the-arctic-tern-1864824.html

[34] NASA (2017).

[35] El-Nouby Adam, M. (2010) Effect of Stratospheric Ozone on UVB Solar Radiation Reaching the Earth's Surface at Qena, Egypt. Atmospheric Pollution Research, 1, 155-160.

[36] Korea Meteorogical Administration.

[37] Duarte, I., Rotter, A., Malevestiti, A. and Silva, M. (2009) The Role of Glass as a Barrier against the Transmission of Ultraviolet Radiation: An Experimental Study. Photodermatology, Photoimmunology \& Photomedicine, 25, 181-184. https://doi.org/10.1111/j.1600-0781.2009.00434.x

[38] Cabrol, N.A., Feister, U., Häder, D.P., Piazena, H., Grin, E.A. and Klein, A. (2014) 
Record Solar UV Irradiance in the Tropical Andes. Frontiers in Environmental Science, 2, 19. https://doi.org/10.3389/fenvs.2014.00019

[39] Callahan, K. (2006) The Global Avian Influenza Network for Surveillance (GAINS) Program Design and Organizational Plan and Analysis. Workshop Final Report.

[40] Yoon, S.W., Webby, R.J. and Webster, R.G. (2014) Evolution and Ecology of Influenza a Viruses. Current Topics in Microbiology and Immunology, 385, 359-375.

[41] Food and Agriculture Organization of the United Nations. Global Information and Early Warning System on Food and Agriculture (GIEWS). http://www.fao.org/giews/en/

[42] Liu, D., Shi, W.F. and Gao, G.F. (2014) Poultry Carrying H9N2 Act as Incubators for Novel Human Avian Influenza Viruses. The Lancet, 383, 869. https://doi.org/10.1016/S0140-6736(14)60386-X

[43] McCabe, W.L. and Smith, J.C. (1976) Unit Operations of Chemical Engineering. 3rd Edition, McGraw-Hill, New York.

[44] Doran, P.T., McKay, C.P., Clow, G.D., Dana, G.L. and Fountain, A.G. (2002) Valley Floor Climate Observations from the McMurdo Dry Valleys, Antarctica, 1986-2000. Journal of Geophysical Research, 107, 4772. https://doi.org/10.1029/2001JD002045

[45] Noti, J.D., Blachere, F.M., McMillen, C.M., Lindsley, W.G., Kashon, M.L., Slaughter, D.R. and Beezhold, D.H. (2013) High Humidity Leads to Loss of Infectious Influenza Virus from Simulated Coughs. PLOS ONE, 8, e 57485.

https://doi.org/10.1371/journal.pone.0057485

[46] https://www.nature.com/articles/srep18094/figures/1

[47] Stallknecht, D.E., Kearney, M.T., Shane, S.M. and Zwank, P.J. (1990) Effects of pH, Temperature, and Salinity on Persistence of Avian Influenza Viruses in Water. Avian Diseases, 34, 412-418.

[48] Sagripanti, J.L. and Lytle, C.D. (2007) Inactivation of Influenza Virus by Solar Radiation. Photochemistry and Photobiology, 83, 1278-1282.

[49] (2005) AI Outbreaks: OIE, FAO, and Government Sources. Flyways: Wetlands International.

[50] Ministry of Agriculture, Food and Rural Affairs (2016). 